\title{
Outcomes of Presidential Elections and the House Size
}

Article in Political Science and Politics · October 2003

CITATIONS

18

2 authors:

Michael G. Neubauer

California State University, Northridge

26 PUBLICATIONS 231 CITATIONS

SEE PROFILE
READS

36

Joel Zeitlin

California State University, Northridge

11 PUBLICATIONS 94 CITATIONS

SEE PROFILE

All content following this page was uploaded by Joel Zeitlin on 11 September 2017. 


\title{
Outcomes of Presidential Elections and the House Size
}

\author{
Michael G. Neubauer, California State University, Northridge \\ Joel Zeitlin, California State University, Northridge
}

A much discussed paradox of the 2000 Presidential election is the fact that despite winning the popular vote, $\mathrm{Al}$ Gore lost the election to George W. Bush. This is, of course, due to the fact that the president is not elected by a plurality of popular votes cast but rather by a plurality of votes of the 538-member Electoral College (EC). Each state, except for Maine and $\mathrm{Ne}$ braska, elects its members of the EC by a winner-take-all method, i.e., the winner of the plurality vote in a state is entitled to all the electors from that state. ${ }^{1}$ The only other winning candidate without a plurality of the popular vote was in the Harrison v. Cleveland election of 1888. While the 1888 election still produced a difference of 65 votes in the EC in favor of Harrison, the 2000 election was also very close in the EC. Only the 1876 Hayes v. Tilden election was closer in EC votes.

The size of each state's delegation to the EC equals the size of the state's delegation in the House of Representatives plus two for its senators. The reasons for this method of apportionment of the EC members are rooted in the Connecticut Compromise of 1787 (Kelly, Harbinson, and Belz 1970; Koppell 2000). Furthermore, the 23rd Amendment to the U.S. Constitution, ratified in 1961, gives the District of Columbia the same number of members in the EC as the smallest state. Currently, this number is 3 , the number of EC members for several states. Since the size of each state's EC delegation is equal to the size of its delegation in the House plus two, smaller states have a relatively larger representation in the EC than they would if $\mathrm{EC}$ members were apportioned based on the population size alone. For example, in the 2000 election the 22 smallest states had a total of 98

Michael G. Neubauer is professor of mathematics at California State University, Northridge. He works in linear algebra and combinatorics.

Joel Zeitlin is professor of mathematics at California State University, Northridge. He is interested in geometry and mathematical computing. votes in the $\mathrm{EC}$ while their combined population was roughly equal to that of the state of California, which had only 54 votes in the EC. Of those $98 \mathrm{EC}$ votes, 37 went for Gore while 61 went for Bush. These inequities are well known (Dahl 2002); we will not discuss them further here.

In 1941, the size of the House was fixed at 435 representatives and has not been changed since. ${ }^{2}$ Though the size of the House has not increased during the last 60 years, the population increased from about 131 million people in 1940 to about 290 million people in 2000. In 1941 , there was approximately one representative for every 301,000 citizens. In 1990 , there was approximately one representative for every 572,000 citizens. If we wanted the same ratio of representatives to people today as existed in 1941 then the House, based on the 1990 census, should have had about 830 members while based on the 2000 census the current House should have about 940 members. Since our interest is in the 2000 presidential election we use the 1990 census figures which were used for the apportionment of electors in the 2000 election. We apportioned a hypothetical House with 830 members and, using the official results of the 2000 presidential election from all 50 states and the District of Columbia, added up the electoral votes for Bush and Gore under this scenario. The result of this thought experiment is that Gore has 471 of the $934 \mathrm{EC}$ votes versus 463 votes for Bush. Hence Gore would have been the winner of the election if the House size had been 830 in 2000 . It is this surprising result that inspired this article.

We then carried out the apportionment of the House for all House sizes between 50 and 1000. As our example for the House size 830 indicates, we expected Gore to win for large House sizes and Bush to win for small House sizes as he did with the House size at 435. The actual results are more surprising. As the House size ranges from 50 to 1000 , the 2000 election would have produced ties for the following 25 House sizes: 491, 493, 505, 507, 533, $535,537,539,541,543,545,547,551$, $555,557,559,561,571,573,585,587$,
591, 593, 597, and 655. For all House sizes larger than 597, save for 655 , which results in a tie, Gore would have won the election. For all House sizes smaller than 491 Bush would have won the election. The would-be winner for each House size is listed in Table 1.

Perhaps the most troubling aspect of the information in Table 1 is the fact that for House sizes between 492 and 596 the winner goes back and forth many times without much rhyme or reason. For those 105 different House sizes, the election ends in a tie 23 times, Gore wins 29 times, and Bush wins 53 times.

To put it as a punch line: The winner of the 2000 presidential election was determined in 1941 when the House size was fixed at 435 . Had the House size been set at 500 in 1941 (and not been changed since) then Gore would have won the 2000 election!

As an illustration, we describe the reasons for the different outcomes for the House sizes 490, 491, and 492 . With a House size of 490 , Bush wins the election by one vote, a House size of 491 results in a tie while a House size of 492 results in Gore winning the election by one vote. Increasing the House size from 490 to 491 causes the state of New York to gain an extra seat while all other states have the same apportionment as they did with a House size of 490. Since Gore won New York, the election now results in a tie. When we increase the House size from 491 to 492 the extra seat goes to Pennsylvania. Since Gore won that state he now wins the election by one vote. Graph 1 plots House sizes between 50 and 1000 on the horizontal axis and the corresponding difference in electoral votes on the vertical axis. Positive differences mean that Bush wins and negative differences mean that Gore wins.

Though the global picture clearly shows the general tendency for the difference to decrease this is not necessarily obvious when we look at smaller intervals. Graph 2 extracts the graph for the House sizes between 480 and 610 for a more in-depth look. Notice the steep increase in the difference from a House size of 498 and a House size of 511. Over this interval of House sizes 
Table 1

\begin{tabular}{llclcl}
\hline $\begin{array}{c}\text { House } \\
\text { size }\end{array}$ & winner & $\begin{array}{c}\text { House } \\
\text { size }\end{array}$ & winner & $\begin{array}{c}\text { House } \\
\text { size }\end{array}$ & winner \\
\hline$<491$ & Bush & 541 & tie & $562-570$ & Bush \\
491 & tie & 542 & Bush & 571 & tie \\
492 & Gore & 543 & tie & 572 & Bush \\
493 & tie & 544 & Bush & 573 & tie \\
$494-504$ & Gore & 545 & tie & $574-584$ & Gore \\
505 & tie & 546 & Bush & 585 & tie \\
506 & Gore & 547 & tie & 586 & Gore \\
507 & tie & $548-550$ & Gore & 587 & tie \\
$508-532$ & Bush & 551 & tie & $588-590$ & Bush \\
533 & tie & $552-554$ & Bush & 591 & tie \\
534 & Gore & 555 & tie & 592 & Gore \\
535 & tie & 556 & Bush & 593 & tie \\
536 & Bush & 557 & tie & $594-596$ & Bush \\
537 & tie & 558 & Bush & 597 & tie \\
538 & Bush & 559 & tie & $598-654$ & Gore \\
539 & tie & 560 & Bush & 655 & tie \\
540 & Gore & 561 & tie & $>655$ & Gore \\
\hline
\end{tabular}

the difference in electoral votes increases from -5 to +4 . Over this interval states that gain seats are states Bush won in 2000 with the exception of New York and California.

The number of electoral votes for Bush minus the electoral votes for Gore changes by one each time the house size increases by one seat. ${ }^{3}$ Whether the change is in favor of Bush or in favor of Gore depends on which state gains the extra seat. As the House size increases from 491 to 597 , the winner changes repeatedly depending on which order the states gain the additional seats. This order depends intricately on population sizes and cannot be discerned a priori. The following observations ex- plain the behavior for small House sizes and large House sizes. For large House sizes the relative representation of the states in the EC becomes closer to their relative representation in the House. Since Gore won the popular vote, it is hence not surprising that he would have won the election for large House sizes. Our earlier example shows that for small House sizes smaller states have a relatively larger percentage of the members in the EC. This is the reason Bush would have won the election with small House sizes. The interval between 491 and 597 falls between the two extremes, which is reflected in the repeated change of the winner from Bush to Gore and vice versa. Bush's electoral strategy of winning many small states, without winning the big states of California and New York, worked! However, it only worked because the House size was small enough. The non-monotonicity of the difference in the electoral votes for the two candidates with respect to the House size is not unlike the Alabama paradox, which led to Hamilton's method being abandoned in 1901 as the

\section{Graph 1}

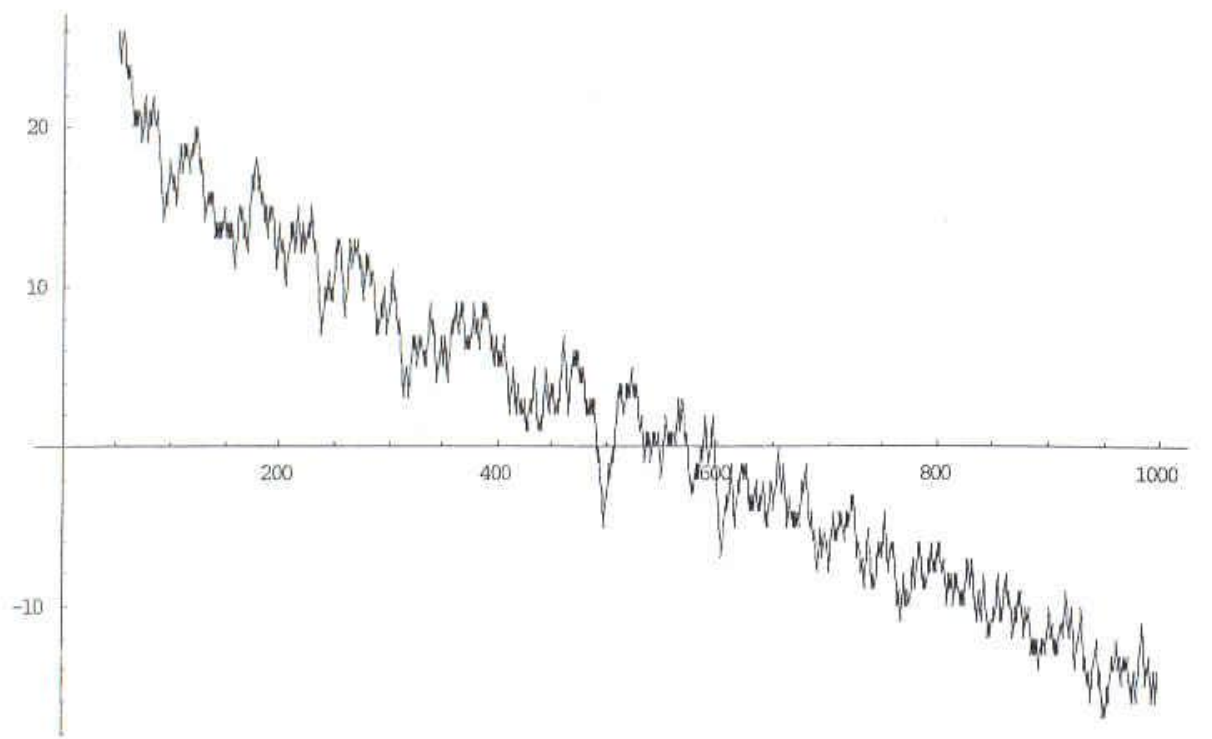

method of apportionment in the U.S. With Hamilton's method of apportionment it may happen, as it did with $\mathrm{Al}$ abama after the 1880 census, that the House size increases yet one or more states lose a seat (see Tannenbaum and Arnold 2001, for examples). This, in turn, may cause the number of electoral votes for a candidate to drop even when the size of the House is increased by one. With the current apportionment method, this rather undesirable behavior cannot happen. Nevertheless, the difference in the number of votes for two candidates shows the same non-monotonic behavior with respect to the House size that we see with the Alabama paradox in Hamilton's method.

These observations show that our present method not only goes against the popular vote in the recent election but this instability further highlights the fact that the election of our president by a supposedly fair and trustworthy method depends capriciously on the choice of the House size. We believe that this is a major flaw of the current method of electing a president. We offer this fact as an argument that can be used against the use of the EC in electing the President. Of course, abolishing the current election method requires a constitutional change and as such would require the approval of Congress and ratification by 37 states. Most states are small and benefit from having their proportional share in representation augmented by those two electoral votes corresponding to Senate seats; it would seem unlikely that these states would give away this power. More importantly, perhaps, it would undo a good part of the work of the framers of the Constitution. Without the Connecticut Compromise there might not even be a United States and thus no basis for this discussion.

However, this does not prevent us here from playing with a few what-if scenarios to see how the 2000 election would have turned out under different circumstances. The first two scenarios would require constitutional changes and are therefore unlikely to be of any practical significance. The third scenario does not require a constitutional change.

Electing the president by a plurality of the votes eliminates the EC and its idiosyncrasies altogether. One drawback to a direct vote is the "Nader factor"; a 3rd party candidate that draws votes disproportionately away from one candidate over the other, thereby influencing the election. Undoubtedly, the "Nader factor" played a role in the 2000 election in Florida but it was not strong enough for Gore to lose the popular vote in the whole country. The perils of 


\section{Graph 2}

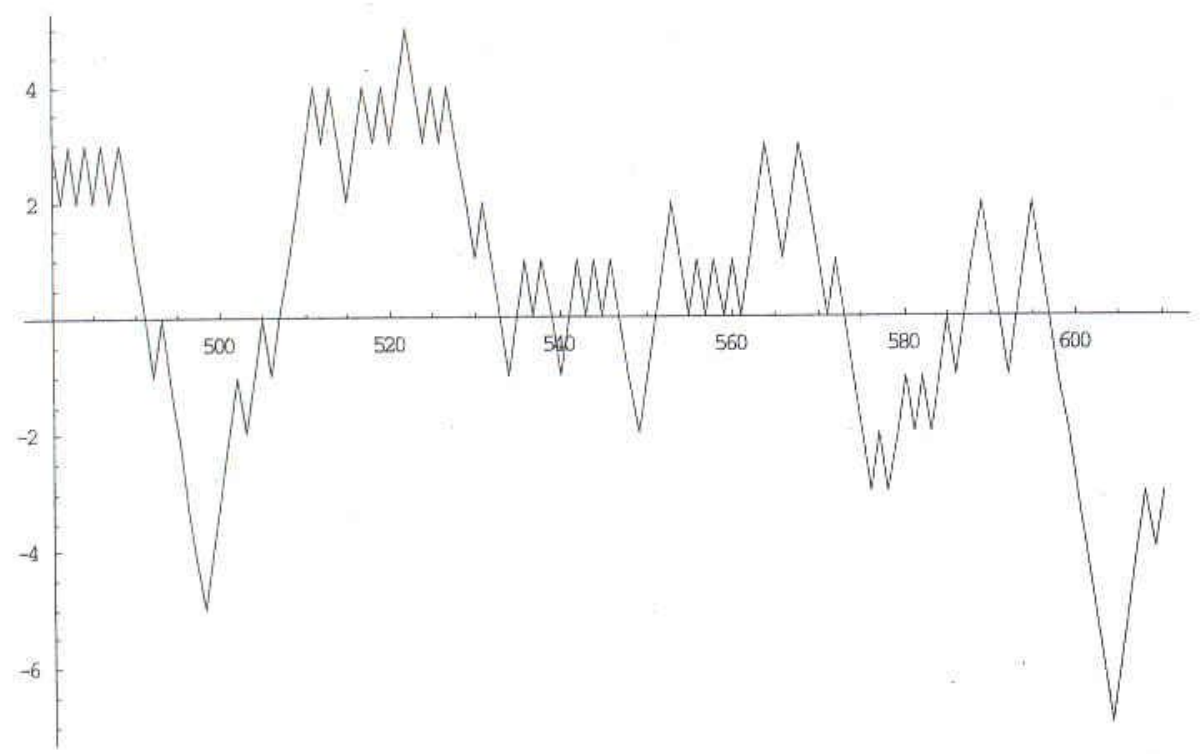

voting theory are probably better known through Arrow's Theorem (Arrow 1951) and through the more recent work of Saari (Saari 1994 and 2001). A direct election of the president does offer the advantage that it is independent of the House size.

Another possibility is a modified EC with the size of each state's delegation equal to the number of its representa-

Table 2

\begin{tabular}{llllrr}
\hline & B & G & & B & G \\
\hline Wyoming & 3 & 0 & SouthCarolina & 8 & 0 \\
Alaska & 3 & 0 & Arizona & 7 & 1 \\
Vermont & 0 & 3 & Kentucky & 7 & 1 \\
North Dakota & 3 & 0 & Alabama & 8 & 1 \\
Delaware & 0 & 3 & Louisiana & 8 & 1 \\
South Dakota & 3 & 0 & Minnesota & 5 & 5 \\
Montana & 3 & 0 & Maryland & 4 & 6 \\
Rhode Island & 0 & 4 & Washington & 3 & 8 \\
Idaho & 4 & 0 & Tennessee & 8 & 3 \\
New Hampshire & 3 & 1 & Wisconsin & 4 & 7 \\
Hawaii & 0 & 4 & Missouri & 8 & 3 \\
Nevada & 3 & 1 & Indiana & 10 & 2 \\
Maine & 0 & 4 & Massachusetts & 0 & 12 \\
New Mexico & 1 & 4 & Virginia & 10 & 3 \\
Nebraska & 5 & 0 & Georgia & 11 & 2 \\
Utah & 5 & 0 & North Carolina & 11 & 3 \\
West Virginia & 4 & 1 & New Jersey & 2 & 13 \\
Arkansas & 4 & 2 & Michigan & 7 & 11 \\
Kansas & 6 & 0 & Ohio & 13 & 8 \\
Mississippi & 7 & 0 & Illinois & 9 & 13 \\
lowa & 3 & 4 & Pennsylvania & 10 & 13 \\
Oregon & 3 & 4 & Florida & 15 & 10 \\
Oklahoma & 8 & 0 & Texas & 22 & 10 \\
Connecticut & 0 & 8 & NewYork & 4 & 29 \\
Colorado & 6 & 2 & California & 19 & 35 \\
\hline & & & & & \\
& & & & & \\
\hline
\end{tabular}

presidential election Bush would have won 19 of California's 54 electors since he won the plurality of votes in 19 of California's congressional districts. Gore would have won the remaining 35 electors; 33 of those as a result of winning the plurality of votes in congressional districts and two of those for winning the plurality of votes in the state. Under the current system, Gore won all 54 electors. In all 50 states plus the District of Columbia, Bush would have won 289 of the electoral votes to Gore's 249. Table 2 lists the results of the presidential election under this scenario for all states. Minnesota's 10 electors are split equally between the two candidates; Bush winning in five congressional districts and Gore winning three congressional districts and the plurality of votes in the state. In all other states, the winner of the statewide plurality vote is the candidate with more electoral votes. Note that Gore would also win the three electors for D.C.

Districts with Republican representatives tended to vote Republican in the presidential election, while districts with Democratic representatives tended to vote Democratic with the exception being mostly southern districts held by conservative Democrats that voted Republican. At first sight, this method promises to allocate electors to the candidates at numbers closer to the actual percentage of votes a candidate receives in a given state. This is in fact true for some of the bigger states. In Illinois, Bush won $43 \%$ of the vote and would have won $41 \%$ of its electors under this method while Gore won $53 \%$ of the votes and would have won $56 \%$ of its electors. These numbers compare favorably to the $0 \%$ of the electors for Bush and $100 \%$ of the electors for Gore allocated in the actual election. However, while this method allows a big state to achieve a more equitable allocation of its electors it hardly changes the allocation of electors in a small state. In the 10 smallest states, only one elector would have been allocated differently. Since more of the small states are solidly Republican this method would present serious challenges for Democratic presidential politics. A deficit of four electoral votes would grow to a deficit of 43 votes. This method also depends on the House size and very heavily on the composition of the resulting districts in the states. Its effects with regard to a changing House size are very hard to estimate.

Some readers may wonder if we are calling for a revision of our electoral system. We are not, since, as we point out above, it is politically unlikely that the system will change and there are 
some positive reasons to support the current system. We present the above arguments as a contribution to informed discussion. We do not pretend to know what other considerations might arise in the future but feel that careful consideration of our electoral system requires understanding rather than unfaulting advocacy. It is not the nature of our system to rest upon divine or unquestioned perfection of the rules but to believe in ongoing consideration. We are reminded of Robert Nozick's (Nozick 1968, pp. xii-xiv) comments: "Works of philosophy are written as though their authors believe them to be the absolutely final word on their subject. ... Why do they strive to force everything into that one fixed perimeter? What does having everything within a perimeter do for us? Why do we want it so? .... I propose to give it all to you: the doubts, and worries and uncertainties as well as the beliefs, convictions, and arguments."

\section{Appendix}

Though apportionment appears at first sight to be a straightforward problem that should allow for a satisfactory answer, the real story is quite a bit more complex. During the last 225 years of U.S. history several methods of apportionment have been in use. Tannenbaum and Arnold's book

(Tannenbaum and Arnold 2001) gives a nice summary of dates of importance to the history of apportionment in the U.S. We can only offer a small glimpse at the subtleties of apportionment. We refer the interested reader to Balinski and Young's definitive treatment (Balinski and Young 2001). The U.S. Constitution prescribes the apportionment of the EC based on the apportionment of the House but it does not specify a method of apportionment for the House.

The first attempt at solving the apportionment problem usually revolves around the idea of the natural divisor: For any given size of the House. which we call $\mathrm{H}$, and a given total population

of the U.S., which we call P. we define the natural divisor $\mathrm{D}=\mathrm{P} / \mathrm{H}$. The natural divisor $\mathrm{D}$ measures the number of people per representative. If $\mathrm{D}=450.000$ then we say that there is one representative for every 450,000 citizens. If we now divide the population of each state by $D$ we get a natural quota for each state. As

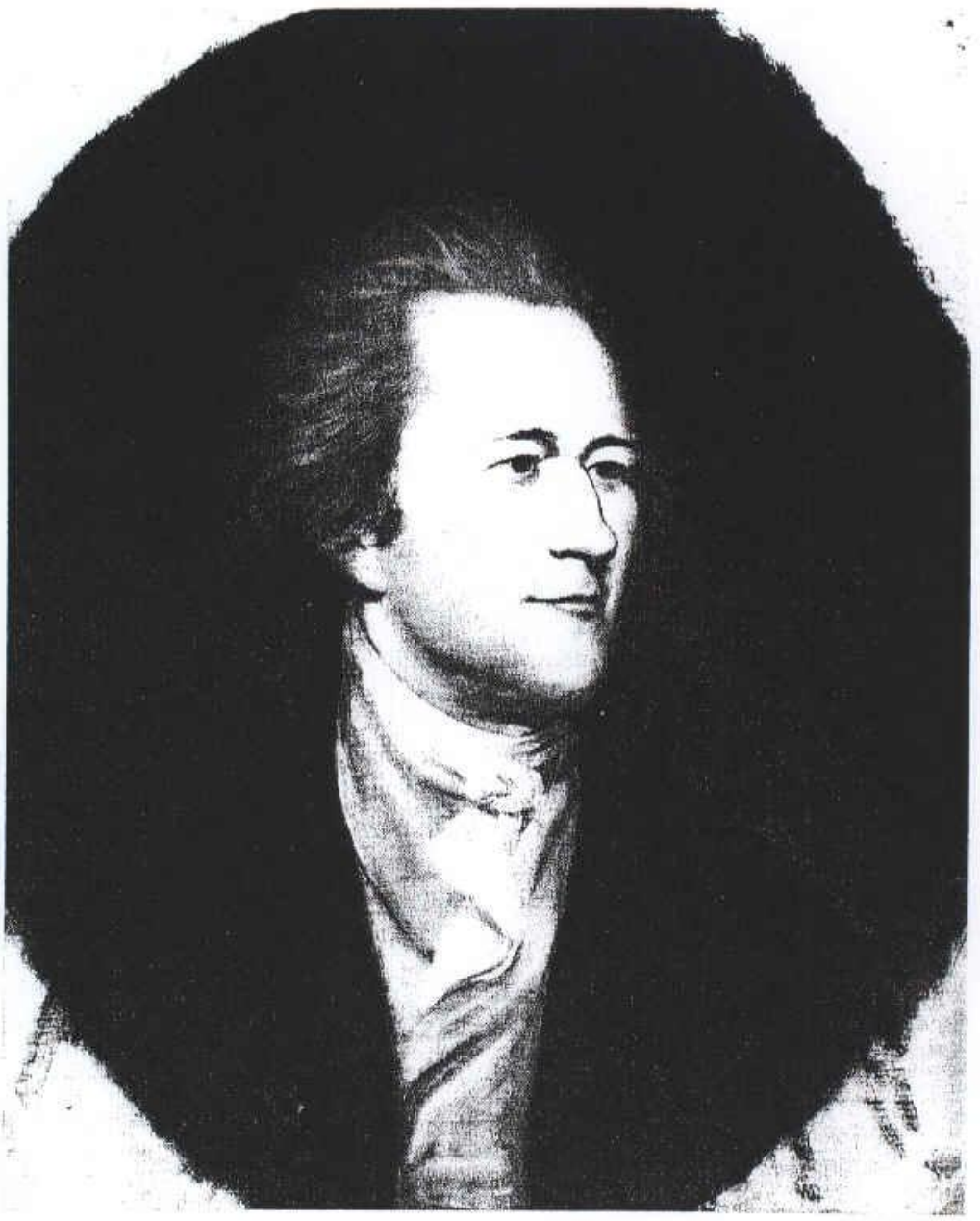

Common sense? Alexander Hamilion's method for apportioning House seats proved sensible until 1911, when it was doomed by the Alabama paradox. Photo: Independence National Historical Park Collection.

the reader will have probably noticed, the natural quota is almost never a whole number but involves fractional parts.

Unfortunately, it is impossible to come up with good rules to deal with the inevitable fractional parts of the natural quotas. For example, if a state's natural quota is 11.567 then we need to decide if the state should get 11 or 12 representatives. Rounding conventionally. i.e.. rounding up above .5 and rounding down below 5 , leaves us in most cases with either too many or too few representatives and is therefore not an option.

Alexander Hamilton proposed the following apparently sensible nethod: Give each state its natural quota rounded down, in our example 11, and then apportion any extra seats based on the size of the fractional parts of the natural quota, with the states with largest fractional parts each getting one extra seat until the correct number is reached.

Hamilton's, aka Vinton's, method leads to the following paradox, called the $\mathrm{Al}$ abama Paradox. In 1880, with the size of the House at 299, Alabama would have been entitled to eight seats while, with the size of the House at $300, \mathrm{Al}-$ abama would have been entitled to only seven seats. It seemed highly undesirable for a state's apportionment to go down as the size of the House increases. This problem finally doomed Hamilton's method in 1911 after Congress had adopted it in 1852. Any replacement of Hamilton's method needed to have the "House size property," i.e., an increase in the size of the House cannot lower the apportionment of any state. Balinski and Young (Balinski and Young 2001) have shown that any apportionment method based on natural quotas will produce the Alabama paradox in some instances.

The other idea used to solve the apportionment problem revolves around the district sizes. If a state's apportionment is $\mathrm{N}$ representatives while its population is P, then the average district size is $P / N$. In fact, the courts have ruled that in drawing their districts the states insure that every district size is very close to the quotient $\mathrm{P} / \mathrm{N}$.

An obvious goal now is to make the district sizes in all states "as equal as possible." However, it is this notion of "as equal as possible" that is the cause for disagreement; several competing methods have been proposed on how to measure "as equal as possible." We describe two different measurements that lead to different apportionment methods followed by an example to illustrate their difference. First, we owe the reader an explanation of the terminology. The absolute difference of two positive numbers $A$ and $B$, where $A$ is greater than $B$, is $A-B$. Their relative difference is $(A-B) / B$. 
Dean's method apportions to each state a number of seats such that no transfer of one seat from one state to another state lowers the absolute difference of the average district sizes of the two states, i.e., the absolute differences of the average district sizes are minimized. The Method of Equal Proportions or Huntington-Hill method is different only in that it uses the relative differences as the criterion for a transfer of seats.

The apportionment method currently in use is the Method of Equal Proportions or Huntington-Hill method. How it got to be named Method of Equal Proportion is a story told very well by Balinski and Young (Balinski and Young 2001). Let it be said here only that naming it the Method of Equal Proportions was for the purpose of making it appear to be the only unbiased among

\section{Notes}

1. Maine and Nebraska give an elector to the winner of the plurality of votes in each congressional district and in addition give two electors to the winner of the plurality of the statewide vote. It is therefore possible that the five Nebraska electors and several apportionment methods. That it is, in fact, biased has been argued repeatedly (see, e.g., Balinski and Young 2001; Poston 1997).

The following example explains the difference in the two methods. It gave rise to the Supreme Court case U.S. Department of Commerce y. Montana, No. 91-860. In the 1990 census, Montana's population was determined to be 803,655 and the state of Washington's population was determined to be $4,887,941$. Montana was apportioned one seat while Washington received nine seats. The district size for Montana was 803,655 while the district size for Washington was $4,887,941 / 9=543,104.55$. The absolute difference of these two numbers is $260,550.44$ while their relative difference is 0.480 .

Now consider a transfer of one seat from Washington to Montana, i.e.,
Montana has now two seats while Washington has only eight. The new district sizes are 401,827.5 for Montana and $610,992.625$ for Washington. The absolute difference of the new district sizes is $209,165.125$ while the relative difference now is 0.521 .

Thus, a transfer of one seat from Washington to Montana results in a decrease of the absolute difference of the district sizes and according to Dean's method this transfer should then happen. However, the same transfer leads to an increase in the relative difference of the district sizes and hence violates the stipulation of the Huntington-Hill method. The Supreme Court agreed with the Department of Commerce by ruling that the HuntingtonHill method meets constitutional requirements and Montana did not gain a second seat.

\section{References}

Arrow, Kenneth J. 1951. Social Choice and Individual Values. New York: Wiley.

Balinski, Michael L., and H. Peyton Young. 2001. Fair Representation: Meeting the Ideal of One Man, One Vote. 2nd edition, Washington D.C.: Brookings Institute.

Dahl, Robert A. 2002. How Democratic is the American Constitution? New Haven: Yale University Press.

Maine's four electors are split between several candidates:

2. During the 87 th Congress 1961-1963, after Hawaii and Alaska had joined the Union, the House size was 437 to give the two new states representation. However, the apportionment following the 1960 census was based again on a House size of 435 .

3. While this seems obvious it is not true for all apportionment methods but is true for the current apportionment method.
Kelly, Alfred H., Winfred A. Harbison, and Herman Belz. 1970. The American Constitution: Its Origins and Development. 4th ed. New York: W. W. Norton Company.

Koppell, Jonathan G. S. 2000. "Some States are More Equal than Others," Los Angeles Times editorial. November 9.

Nozick, Robert. 1968. Anarchy, State, and Utopia. New York: Basic Books, lnc.
Poston, Dudley L. 1997. "The U.S. Census and Congressional Apportionment." Society 34(March/April).

Saari, Donald G. 1994. Basic Geometry of Voting. New York: Springer-Verlag.

Saari, Donald G. 2001. Decisions and Elections. Cambridge: Cambridge University Press.

Tannenbaum, Peter, and Robert Arnold, 2001 Excursions in Modern Mathematics. 4th ed. New York: Prentice Hall. 